\title{
The Use of Pictures Story in Improving Students' Ability to Write Narrative Composition
}

\author{
Andi Asrifan \\ English Education Department, the institute of teachers training and education of Muhammadiyah Rappang, Sidenreng Rappang Regency, \\ South Sulawesi, Indonesia \\ Email address: \\ andiasrifan@yahoo.co.id \\ To cite this article: \\ Andi Asrifan. The Use of Pictures Story in Improving Students' Ability to Write Narrative Composition. International Journal of Language \\ and Linguistics. Vol. 3, No. 4, 2015, pp. 244-251. doi: 10.11648/j.ij11.20150304.18
}

\begin{abstract}
The objective of the research was to find out whether or not the use of pictures story can improve the students' writing ability in terms of content, organization, vocabulary, language use, and mechanics to narrative composition. This research employed Quasi-experimental method that applied experimental and control class. The population was the first year students (X) of SMA Negeri 3 Parepare in 2013/2014 academic years. Total number of population was 192 students. In sampling process, the researcher used random sampling because the researcher considered that the populations were heterogenic members. In addition, the numbers of students in first year of SMA Negeri 3 Parepare were too large. This sample of this research took I.E as experimental class with 38 students and I.D as control class with 40 students. The result of this research showed that the experimental group got the mean score (75.80) while the control group got mean score (68.03). This showed that there was significant difference between the students who were taught by using Pictures Story and those who were taught without Pictures Story. The result of the t-test value (2.63) was greater than t-table (alpha two-tailed $=0.05: 72=2.000$ ). This means that H1 was accepted. The study concluded that teaching writing by using Pictures Story increased the students' ability to write narrative composition at SMA Negeri 3 Parepare.
\end{abstract}

Keywords: Pictures Story, Writing Skill, Narrative Composition

\section{Introduction}

Writing means filling the gap that exists among the ability to express ideas, feelings, and opinions. It is widely admitted that writing is a crucial communication that could not be separated from human life. Writing is an instrument of both communication and self-expression (Pincas, 1986). Writing has an important role when a writer wants to deliver a message to a reader for a purpose. Through writing, the writer can explain things and as a result readers can get information by reading the written message.

Writing is taught as one of four language skills in English and it is one activity that the students do most in their study. Through writing assignments, the students can express their ideas, respond to the other ideas, tell stories, convey information, and they are expected to be able to compose well-organized writing. Writing ability also can be the ticket to better college grades and greater academic achievement.

On the other hand, there are many students find difficulty when they are asked to write because they do not know how to start and what topic that they should choose. Besides, uninteresting topic and unsuitable teaching techniques can influence students' interest in writing English.

To break through the problem, English teachers have to be more creative in choosing the materials and techniques which can make the writing class more interesting, exciting and enjoyable. It can be done by choosing an appropriate material and technique that students like based on students' level and background of knowledge. Ali (2009) argues that to boost the students' writing ability, the students have to be creative, create the environment that will allow the creativeness of the students, know ourselves deeply, intimately or patiently with the process of writing, free ourselves from outcome and enjoy the process, have compassion, no doubt, no fear, do not say 'I cannot', learn all the time and do the experiment, and be unique. Some points that he proposed show that the students have to be interested and enjoy the writing process to improve the students writing ability. 
Many teachers make efforts to make their class interesting with various methods, techniques, and materials in order to stimulate learning of language skills effectively. The teachers must be able to create situation that provides opportunities and stimulates the students especially to be interested in writing and it is not impossible if they use an authentic material to make the students more enjoy the writing process. The use of authentic materials in an EFL classroom is what many teachers involved in foreign language teaching have discussed in recent years.

An authentic material means material which is not designed for language teaching purposes, but it is brought into the classroom such as real newspaper reports, magazine articles, advertisements, cooking recipes, songs, and also pictures story. Kilickaya (2004) realized that most of the teachers throughout the world agree that authentic texts or materials are beneficial to the language learning process.

In relation to the previous explanation, materials are divided into two points they are visual and non-visual material. A visual material offers an attractive and stimulating framework for writing practice and has great potential as an aid to develop writing skills since it provides both contexts and stimulation for a variety of activities. One of the visual materials is picture. While non-visual material also is used in stimulating students to comprehend the subject and one of the non-visual materials is sound or we can say as audio. In relation to the teaching writing process, the teacher can combine the two kinds of materials above. They can use audio-visual material as the authentic material in teaching writing to make the students more interested to write based on the given topic.

Teaching using picture story is very suitable to be applied to the students of senior high school as a media in writing and also is very helpful for the students in generating and organizing their ideas in writing through picture.

Pictures story speaks thousands of words, it can be very effecttive way of teaching and learning english language especially in teaching and writing, as Heaton (1988: 142) says that a pictures story are very useful. It is not only used as the basic materials for students composition but also it is effectively stimulates students' imaginative power. So that pictures story can be very effective way of teaching and learning the English Language especially writing.

English is an important subject for senior high school students because they will use it for their future. Therefore, writing ability is considered as a very important skill for the students to develop their mastery in English proficiency. When the researcher had done observation about writing vocused on narative text in SMA Negeri 3 Parepare, the researcher found the students' writing in English was very poor. The averages of students' writing were 65.00 it means that they have very low ability compared to the English minimal standard grade (KKM). While the minimum of mastery learning criteria or KKM is 70.00 . Therefore the researcher focuses on teaching writing through picture story in English learning. Moreover, the English teacher seldom tries to motivate them to use the interesting ways in composing writing. It means that students do not have good ideas to start their writing. Consequently, clustering is one of the simple ways to help them in building their mind. It will guide them to make sentences until a good paragraph.

Based on the explanation above, the researcher focuses to take sample on the SMA Negeri 3 Parepare especially students of the first year because there is problem the researcher found in writings. In addition, there is much information got from the English teacher that most of them do not have many ideas or do not have good strategy in doing writing activity.

Based on the result of observation, the researcher interested to conduct a research entitled "the use of pictures story in improving students' ability to write narrative composition".

\section{Methods}

\subsection{Population and Sample}

The population of this research was first year students of SMA Negeri 3 Parepare in academic year 2013/2014. There were five classes, namely: I.A, I.B, I.C, I.D, and I.E. One class had 40 students and the others had 38 students. Therefore, the number of population was 192 students.

In sampling process, the researcher used random sampling because the researcher considered that the populations were heterogenic members. In addition, the numbers of students in first year of SMA Negeri 3 Parepare were too large. This sample of this research took I.E as experimental class with 38 students and I.D as control class with 40 students.

\subsection{Instrument of the Research}

The researcher used writing test as instrument in collecting data. The function of this test is to know the students' ability is writing narrative composition to analyzee its content, organization, vocabulary, language use, and mechanics.

\subsection{Procedure of Collecting Data}

Procedure of collecting data was divided into two stages, namely pre-test and post-test.

1. Pre-test

Before giving treatment, the researcher gave writing test to the students in written form with some steps. The pre-test was done for 90 minutes and given to both of groups, experimental and control class

2. Post-test

After doing the treatment, the researcher gave a posttest. The researcher applied posttest to point out students' achievement in writing skill writing by using pictures story. The post-test was done for 90 minutes.

\subsection{Treatment}

The researcher gives treatment to the students, both experimental and control class. The experimental class was given the treatment by using pictures story. The control class 
received treatment without using pictures story and used conventional method. Both of the groups learn the same materials.

\subsubsection{Experimental Class}

For experimental class, the researcher gave the treatment in six times. The researcher used picture story to be shown to the students. The procedures of giving treatment as follows:

a. The researcher gave prolog and illustration about the pictures story.

b. The researcher introduced the pictures story.

c. The researcher gave some tips to improve and to strengthen the writing skill of the students and gives advice about the organization of paragraph and language use in writing.

d. The researcher explained more about the topics to the student whether they understood about the topic or not and explained more about the steps to write narrative as follows:

1) Pre-writing: preparing a narrative outline.

There were some steps in preparing the outline namely:

a) Chose events for a narrative by giving questions to explore the events of the narrative.

b) Eliminating unnecessary events.

c) Collecting narrative details (people, setting, mood)

d) Giving narrative outline

(1) At the beginning, the writer started to state the purpose of the narrative in an introductory sentence. After that, described the setting, giving important background information, introduced and briefly described the other characters, and began to tell what happened.

(2) In the middle, you may introduce a conflict or problem, show your reaction to the conflict with a direct statement, and build toward a climax and the point of highest interest.

(3) At the ending, the writer wrote the climax, the resolution, and finally adds a conclusion.

2) Writing narrative by focusing on chronological order and coherence and using such transitions as always, before, finally, immediately, meanwhile, and soon to help clarify how events are related in time.

e. The researcher showed the picture story.

f. The researcher instructed the students to write a narration paragraph and gave space for improvisation based on the topic of pictures story.

g. The researcher walked around and monitored students' writing activity.

h. The students might ask the researcher if they found any trouble.

i. The students re-read their paragraph writing and mutually re-checked their paragraphs. j. The students re-write (revised and edited) their paragraphs. Revising means check for transitions that clarify the order of events and for details that help portray the characters, settings, and moods. Edit your work, prepare a final version and proofread it.

k. The researcher and the students discussed and shared about the topic of the pictures story. The teacher and the students also discussed about the components of the students' writing and the teacher gave correction to the students' narrative composition.

1. The researcher asked the students to collect their writing task and informed the students what they would do next and still gave motivation in learning writing.

\subsubsection{Control Class}

For the control class, the researcher gave some conventional treatment without using picture story as an authentic material. The procedure is in the following:

a. The researcher gave some tips to improve and to strengthen the writing skill of the students and gave advice about the organization of paragraph and language use in writing.

b. The researcher explained more about the topics to the student whether they understood about the topic or not and explained more about the steps to write narrative, just like what the researcher explained to the experimental class.

c. Ask the students to do task individually

d. Ask the students to write narrative paragraph related to the topics.

e. Monitor the student activities in the class.

f. Check the students' task correctly.

\section{Results}

Findings

The raw scores of students' writing obtained through writing test were tabulated emphasizing the five components namely, content, organization, vocabulary, language use, and mechanics.

\subsection{Pretest}

The rate of students score is obtained through writing test before giving treatment by using clustering for the experimental group and by using conventional way for the control group. The rate of percentage and frequency for every component in experimental and control group are as follows:

Table 1. Frequency and rate percentage of the writing test score in the content component.

\begin{tabular}{lllllll}
\hline \multirow{2}{*}{ No. } & \multirow{2}{*}{ Qualification } & \multirow{2}{*}{ Score } & \multicolumn{2}{c}{ Experimental } & \multicolumn{2}{c}{ Control } \\
\cline { 4 - 7 } & & F & \% & F & \% \\
\hline 1 & Very good & $86-100$ & - & - & - & - \\
2 & Good & $71-85$ & 2 & 5.26 & 3 & 7.5 \\
3 & Fair & $56-70$ & 15 & 39.47 & 20 & 50 \\
4 & Poor & $41-55$ & 21 & 55.26 & 16 & 40 \\
5 & Very poor & $<40$ & - & - & 1 & 2.5 \\
& Total & & 38 & 100 & 40 & 100 \\
\hline
\end{tabular}


Rate percentage of experimental group in the content component above shows that more than $90 \%$ students cannot make a good writing and their skill in writing still low. Meanwhile the students in control group have the similarity in constructing ideas with the students in experimental group. Mostly, they can relate their ideas with topic but little developing in expressing their ideas.

Table 2. Frequency and rate percentage of the writing test score of the students'writing organization.

\begin{tabular}{lllllll}
\hline \multirow{2}{*}{ No. } & \multirow{2}{*}{ Qualification } & \multirow{2}{*}{ Score } & \multicolumn{2}{c}{ Experimental } & \multicolumn{2}{c}{ Control } \\
\cline { 5 - 7 } & & F & \% & F & \% \\
\hline 1 & Very good & $86-100$ & - & - & 2 & 5 \\
2 & Good & $71-85$ & 13 & 34.21 & 12 & 30 \\
3 & Fair & $56-70$ & 17 & 44.74 & 9 & 22.5 \\
4 & Poor & $41-55$ & 5 & 13.16 & 7 & 17.5 \\
5 & Very poor & $<40$ & 3 & 7.90 & 10 & 25 \\
& Total & & 38 & 100 & 40 & 100 \\
\hline
\end{tabular}

Rate percentage of experimental and control group in the organization component above shows that more than $30 \%$ students can create writing in a good arrangement and involve the writing chronologically. Moreover, more than $60 \%$ students still cannot organize their writing well. Mostly, their main ideas still stand out and construct limited supporting sentences.

Table 3. Frequency and rate percentage of the writing test score of the students' writing vocabulary.

\begin{tabular}{llllllll}
\hline \multirow{2}{*}{ No. } & \multirow{2}{*}{ Qualification } & \multirow{2}{*}{ Score } & \multicolumn{2}{c}{ Experimental } & \multicolumn{2}{c}{ Control } \\
\cline { 5 - 7 } & & F & $\mathbf{\%}$ & F & \% \\
\hline 1 & Very good & $86-100$ & 1 & 2.63 & - & - \\
2 & Good & $71-85$ & 11 & $28.9542,105$ & 14 & 35 \\
3 & Fair & $56-70$ & 16 & 42.11 & 5 & 12.5 \\
4 & Poor & $41-55$ & 5 & 13.16 & 9 & 22.5 \\
5 & Very poor & $<40$ & 5 & 13.16 & 12 & 30 \\
& Total & & 38 & 100 & 40 & 100 \\
\hline
\end{tabular}

Rate percentage of experimental group in the vocabulary component above shows that more than $60 \%$ students still cannot master the writing of words. At the same condition, students in control group have the similarity with the students in experimental group. Most of the students in both groups made many errors in word order.

Table 4. Frequency and rate percentage of the writing test score in the language usage component.

\begin{tabular}{lllllll}
\hline \multirow{2}{*}{ No. } & \multirow{2}{*}{ Qualification } & \multirow{2}{*}{ Score } & \multicolumn{2}{c}{ Experimental } & \multicolumn{2}{c}{ Control } \\
\cline { 5 - 7 } & & F & \% & F & \% \\
\hline 1 & Very good & $86-100$ & 1 & 2.63 & - & - \\
2 & Good & $71-85$ & - & - & 2 & 5 \\
3 & Fair & $56-70$ & 11 & 28.95 & 10 & 25 \\
4 & Poor & $41-55$ & 17 & 44.74 & 13 & 32.5 \\
5 & Very poor & $<40$ & 9 & 23.69 & 15 & 37.5 \\
& Total & & 38 & 100 & 40 & 100 \\
\hline
\end{tabular}

Rate percentage of experimental and control group in the language use component above shows that almost $100 \%$ students construct sentences with many grammatical errors. They made mistake in constructing the sentences for example disorder words constructing rules in writing.
Table 5. Frequency and rate percentage of the writing test score in the mechanics component.

\begin{tabular}{lllllll}
\hline \multirow{2}{*}{ No. } & \multirow{2}{*}{ Qualification } & \multirow{2}{*}{ Score } & \multicolumn{2}{c}{ Experimental } & \multicolumn{2}{c}{ Control } \\
\cline { 5 - 7 } & & F & \% & F & \% \\
\hline 1 & Very good & $86-100$ & - & - & - & - \\
2 & Good & $71-85$ & 1 & 2.63 & 2 & 5 \\
3 & Fair & $56-70$ & 20 & 52.63 & 13 & 32.5 \\
4 & Poor & $41-55$ & - & - & - & - \\
5 & Very poor & $<40$ & 17 & 44.74 & 25 & 62.5 \\
& Total & & 38 & 100 & 40 & 100 \\
\hline
\end{tabular}

Rate percentage of experimental and control group in the mechanics component above shows that almost $100 \%$ students made mistakes in using punctuation and capitalization. Mostly, they are not mastering paragraphing, punctuation, capitalization and made some errors in writing.

\subsection{Posttest}

The rate of students score is obtained through writing test after giving treatment by using pictures story for the experimental group and by using conventional way for the control group. The rate percentage and frequency for every component in experimental and control group as follows:

Table 6. Frequency and rate percentage of the writing test score in the content component.

\begin{tabular}{lllllll}
\hline \multirow{2}{*}{ No. } & \multirow{2}{*}{ Qualification } & \multirow{2}{*}{ Score } & \multicolumn{2}{c}{ Experimental } & \multicolumn{2}{c}{ Control } \\
\cline { 5 - 7 } & & F & $\%$ & F & \% \\
\hline 1 & Very good & $86-100$ & 7 & 17.5 & 3 & 8.33 \\
2 & Good & $71-85$ & 12 & 30 & 11 & 30.56 \\
3 & Fair & $56-70$ & 20 & 50 & 18 & 50 \\
4 & Poor & $41-55$ & 1 & 2.63 & 4 & 11.11 \\
5 & Very poor & $<40$ & - & - & - & - \\
& Total & & 40 & 100 & 36 & 100 \\
\hline
\end{tabular}

Rate percentage of experimental group in the content component above shows that almost $50 \%$ students can make good paragraph assigned with topic. However in control group, only $40 \%$ students have the similarity with the students in experimental group. Mostly, the students in two groups can relate their ideas with topic but still lacks in detail.

Table 7. Frequency and rate percentage of the writing test score of the students' writing organization.

\begin{tabular}{lllllll}
\hline \multirow{2}{*}{ No. } & \multirow{2}{*}{ Qualification } & \multirow{2}{*}{ Score } & \multicolumn{2}{c}{ Experimental } & \multicolumn{2}{c}{ Control } \\
\cline { 4 - 7 } & & F & $\%$ & F & \% \\
\hline 1 & Very good & $86-100$ & 19 & 47.5 & 7 & 19.44 \\
2 & Good & $71-85$ & 15 & 37.5 & 14 & 38.89 \\
3 & Fair & $56-70$ & 4 & 10 & 11 & 30.56 \\
4 & Poor & $41-55$ & 2 & 5 & 3 & 8.33 \\
5 & Very poor & $<40$ & - & - & 1 & 2.78 \\
& Total & & 40 & 100 & 36 & 100 \\
\hline
\end{tabular}

Rate percentage of experimental group in the organization component above shows that almost $90 \%$ students can make a good writing and constructing their ideas clearly. Their writings have logical sequencing and well-organized too. In addition, the other students are still loosely organized and the main idea is standing out. Meanwhile in control group, only $60 \%$ students can make a good organization in their writing. Mostly, their main ideas are standing out and have limited 
supporting sentences.

Table 8. Frequency and rate percentage of the writing test score of the students' writing vocabulary.

\begin{tabular}{lllllll}
\hline \multirow{2}{*}{ No. } & \multirow{2}{*}{ Qualification } & \multirow{2}{*}{ Score } & \multicolumn{2}{c}{ Experimental } & \multicolumn{2}{c}{ Control } \\
\cline { 4 - 7 } & & F & $\mathbf{\%}$ & F & \% \\
\hline 1 & Very good & $86-100$ & 9 & 22.5 & 6 & 16.67 \\
2 & Good & $71-85$ & 23 & 57.5 & 14 & 38.89 \\
3 & Fair & $56-70$ & 6 & 15 & 8 & 22.22 \\
4 & Poor & $41-55$ & 2 & 5 & 8 & 22.22 \\
5 & Very poor & $<40$ & - & - & - & - \\
& Total & & 40 & 100 & 36 & 100 \\
\hline
\end{tabular}

Rate percentage of experimental group in the vocabulary component above shows that $80 \%$ students are good in writing correct words and mastering the word form. However in control group, only $55 \%$ students have the similarity with the students in experimental group who write correct words. Moreover, the others still facing problem in simple construction of words.

Table 9. Frequency and rate percentage of the writing test score in the language usage component.

\begin{tabular}{lllllll}
\hline \multirow{2}{*}{ No. } & \multirow{2}{*}{ Qualification } & \multirow{2}{*}{ Score } & \multicolumn{2}{c}{ Experimental } & \multicolumn{2}{c}{ Control } \\
\cline { 5 - 7 } & & & $\mathbf{F}$ & $\mathbf{\%}$ & $\mathbf{F}$ & $\mathbf{\%}$ \\
\hline 1 & Very good & $86-100$ & 3 & 7.5 & 3 & 8.33 \\
2 & Good & $71-85$ & 18 & 45 & 11 & 30.56 \\
3 & Fair & $56-70$ & 12 & 30 & 10 & 27.78 \\
4 & Poor & $41-55$ & 6 & 15 & 4 & 11.11 \\
5 & Very poor & $<40$ & 1 & 2.5 & 8 & 22.22 \\
& Total & & 40 & 100 & 36 & 100 \\
\hline
\end{tabular}

Rate percentage of experimental group in the language use component above shows that more than $50 \%$ students are good in involving correct language and word order. On the other hand, more than $30 \%$ students in control group have major problem in simple construction and word order. Mostly, they are still lacks in construction rules of writing.

Table 10. Rate percentage and frequency of the writing test score in the mechanics component.

\begin{tabular}{lllllll}
\hline \multirow{2}{*}{ No. } & \multirow{2}{*}{ Qualification } & \multirow{2}{*}{ Score } & \multicolumn{2}{c}{ Experimental } & \multicolumn{2}{c}{ Control } \\
\cline { 5 - 7 } & & & F & \% & F & \% \\
\hline 1 & Very good & $86-100$ & 5 & 12.5 & 3 & 8.33 \\
2 & Good & $71-85$ & 21 & 52.5 & 8 & 22.22 \\
3 & Fair & $56-70$ & 10 & 25 & 15 & 41.67 \\
4 & Poor & $41-55$ & - & - & - & - \\
5 & Very poor & $<40$ & 4 & 10 & 10 & 27.78 \\
& Total & & 40 & 100 & 36 & 100 \\
\hline
\end{tabular}

Rate percentage of experimental group in the mechanics component above shows that more than $60 \%$ students have few errors in using punctuation and capitalization. Meanwhile in control group, almost $70 \%$ students are not mastering punctuation and capitalization. Mostly, they are still lacks in writing.

\subsection{Mean Score and Standard Deviation}

Mean score and standard deviation relates among the five components observed are described in the following tables:
Table 11. Mean score and standard deviation for experimental group.

\begin{tabular}{|c|c|c|c|c|}
\hline \multirow{2}{*}{$\begin{array}{l}\text { Component of } \\
\text { Writing }\end{array}$} & \multicolumn{2}{|c|}{ Pretest } & \multicolumn{2}{|c|}{ Posttest } \\
\hline & $\begin{array}{l}\text { Mean } \\
\text { Score }\end{array}$ & StandardDeviation & $\begin{array}{l}\text { Mean } \\
\text { Score }\end{array}$ & $\begin{array}{l}\text { Standard } \\
\text { Deviation }\end{array}$ \\
\hline a. Content & 53.95 & 8.87 & 72.17 & 11.34 \\
\hline b. Organization & 65.26 & 14.28 & 84.25 & 12.64 \\
\hline c. Vocabulary & 64.21 & 13.53 & 80.88 & 11.49 \\
\hline $\begin{array}{l}\text { d. Language } \\
\text { Use }\end{array}$ & 47,90 & 15.49 & 68.2 & 13.56 \\
\hline e. Mechanics & 51.58 & 11.04 & 73.5 & 16.57 \\
\hline $\begin{array}{l}\text { Writing Skill } \\
\text { Score }\end{array}$ & 56.58 & 11.04 & 75.80 & 11,57 \\
\hline
\end{tabular}

Mean score of pretest for experimental group above shows that for five components are still poor and standard deviation of content and mechanics component is lower than the posttest. It means that the ability of students in writing almost same. Consequently after giving treatment, mean score of posttest for experimental group above shows that for five components are good except for language use component. It means that the students' writing skill in writing narrative paragraph can be improved by using pictures story. Moreover, standard deviation of posttest is higher than in pretest. In other words, the students' ability in receiving materials during treatment process is different.

Table 12. Mean score and standard deviation for control group.

\begin{tabular}{lllll}
\hline \multirow{2}{*}{$\begin{array}{l}\text { Component of } \\
\text { Writing }\end{array}$} & Pretest & \multicolumn{3}{c}{ Posttest } \\
\cline { 2 - 5 } & $\begin{array}{l}\text { Mean } \\
\text { Score }\end{array}$ & $\begin{array}{l}\text { Standard } \\
\text { Deviation }\end{array}$ & $\begin{array}{l}\text { Mean } \\
\text { Score }\end{array}$ & $\begin{array}{l}\text { Standard } \\
\text { Deviation }\end{array}$ \\
\hline a. Content & 55.42 & 9.27 & 67.13 & 9.99 \\
b. Organization & 61.13 & 18.30 & 76.67 & 3.07 \\
c. Vocabulary & 59.13 & 17.76 & 72.92 & 15.35 \\
d. Language Use & 45 & 14.93 & 61.22 & 3.17 \\
e. Mechanics & 48.5 & 11.89 & 62.22 & 15.78 \\
Writing Skill & 53.83 & 12.93 & 68.03 & 13.50 \\
Score & & & & \\
\hline
\end{tabular}

Mean score of pretest for control group above shows that for five components are still poor and standard deviation of organization, vocabulary, and language use component is higher than in posttest. It means that the ability of students in writing is different. Consequently after giving treatment, mean score of posttest for control group above shows that for five components are good except for language use and mechanics component. It means that the students' skill in writing narrative paragraph can be better after using conventional way although by using pictures story can be more effective. Moreover, standard deviation of pretest is higher than in posttest. In other words, the students' ability in receiving materials during teaching process is almost same.

The data resulted from the pretest in both groups were calculated to find out the mean score and the standard deviation of each group.

Table 13. Mean score and standard deviation of students in pretest.

\begin{tabular}{lll}
\hline Group & Mean Score & Standard Deviation \\
\hline Experimental & 56.58 & 10.75 \\
Control & 53.83 & 12.93 \\
\hline
\end{tabular}

The data above shows the mean score obtained by the 
students of experimental and control group are different but not too far. Experimental group is higher than control group.

Table 14. Mean score and standard deviation of students in posttest.

\begin{tabular}{lll}
\hline Group & Mean Score & Standard Deviation \\
\hline Experimental & 75.80 & 11.57 \\
Control & 68.03 & 4.12 \\
\hline
\end{tabular}

After giving different treatment to both groups, the mean score of the students in experimental group is higher than control group. It means that using pictures story can improve the students' writing skill. Moreover in two tests, the standard deviation of control group is higher than experimental group. In this case, the researcher concludes that the students' writing skill have far difference in this group.

Table 15. Mean score and standard deviation of content component.

\begin{tabular}{lllll}
\hline \multirow{2}{*}{$\begin{array}{l}\text { Types of } \\
\text { Test }\end{array}$} & \multicolumn{2}{l}{ Experimental Group } & \multicolumn{2}{l}{ Control Group } \\
\cline { 2 - 5 } & Mean & Standard & Mean & Standard \\
& Score & Deviation & Score & Deviation \\
\hline Pretest & 53.95 & 8.87 & 55.42 & 9.27 \\
Posttest & 72.17 & 11.34 & 67.13 & 9.99 \\
\hline
\end{tabular}

Mean score and standard deviation of content component in pretest above shows that control group is higher than in experimental group. It means that content component for writing narrative paragraph of both groups are similar.

After giving treatment, the mean score and the standard deviation shows that for experimental group are higher than in control group. It means that content component for writing descriptive paragraph of both groups are different. It is caused by the use of pictures story in experimental group and conventional way in control group.

Table 16. Mean score and standard deviation of organization component.

\begin{tabular}{lllll}
\hline \multirow{2}{*}{$\begin{array}{l}\text { Types of } \\
\text { Test }\end{array}$} & \multicolumn{2}{l}{ Experimental Group } & \multicolumn{2}{l}{ Control Group } \\
\cline { 2 - 5 } & Mean & Standard & Mean & Standard \\
& Score & Deviation & Score & Deviation \\
\hline Pretest & 65.26 & 14.28 & 61.13 & 18.30 \\
Posttest & 84.25 & 12.64 & 76.67 & 3.07 \\
\hline
\end{tabular}

The mean score and the standard deviation of organization component in pretest above show that experimental group is higher 4 point than in control group. It means that organization component for writing narrative paragraph of both groups are similar.

After giving treatment, mean score and standard deviation above shows that for experimental group is higher than in control group. It means that organization component for writing descriptive paragraph of both groups are different. It is caused by using pictures story in experimental group and conventional way in control group.

Table 17. Mean score and standard deviation of vocabulary component.

\begin{tabular}{lllll}
\hline \multirow{2}{*}{ Types of } & \multicolumn{2}{l}{ Experimental Group } & \multicolumn{2}{l}{ Control Group } \\
\cline { 2 - 5 } Test & Mean & Standard & Mean & $\begin{array}{l}\text { Standard } \\
\text { Deviation }\end{array}$ \\
\hline Pretest & 64.21 & 13.53 & 59.13 & 17.76 \\
Posttest & 80.88 & 11.49 & 72.92 & 15.35 \\
\hline
\end{tabular}

Mean score and standard deviation of vocabulary component in pretest above shows that experimental group is higher 5 point than in control group. It means that vocabulary component for writing narrative paragraph of both groups are equal.

After giving treatment, mean score above shows that for experimental group is higher and standard deviation is lower than in control group. It means that vocabulary component for writing narrative paragraph of both groups are different. Using pictures story is better than conventional way in improving the students' vocabulary of writing.

Table 18. Mean score and standard deviation of language use component.

\begin{tabular}{lllll}
\hline \multirow{2}{*}{$\begin{array}{l}\text { Types of } \\
\text { Test }\end{array}$} & \multicolumn{2}{l}{ Experimental Group } & \multicolumn{2}{l}{ Control Group } \\
\cline { 2 - 5 } & Mean & Standard & Mean & $\begin{array}{l}\text { Standard } \\
\text { Seviation }\end{array}$ \\
\hline Pretest & 47.90 & 15.49 & 45 & 14.93 \\
Posttest & 68.2 & 13.56 & 61.22 & 3.16 \\
\hline
\end{tabular}

Mean score and standard deviation of language use component in pretest above shows that experimental group is higher 2 point than in control group. It means that language use component for writing narrative paragraph of both groups are same.

After giving treatment, mean score and standard deviation above shows that experimental group is higher than control group. It means that language use component for writing descriptive paragraph of both groups are different. Using pictures story is more effective than conventional way in improving the students' language use of writing.

Table 19. Mean score and standard deviation of mechanics component.

\begin{tabular}{lllll}
\hline \multirow{2}{*}{$\begin{array}{l}\text { Types of } \\
\text { Test }\end{array}$} & \multicolumn{2}{l}{ Experimental Group } & \multicolumn{2}{l}{ Control Group } \\
\cline { 2 - 5 } & Mean & Standard & Mean & Standard \\
& Score & Deviation & Score & Deviation \\
\hline Pretest & 51.58 & 11.04 & 48.5 & 11.89 \\
Posttest & 73.5 & 16.57 & 62.22 & 15.78 \\
\hline
\end{tabular}

Mean score and standard deviation of mechanics component in pretest above shows that experimental group is higher 5 point than in control group. It means that mechanics component for writing narrative paragraph of both groups are equal.

After giving treatment, mean score and standard deviation for experimental group is higher than control group. It means that mechanics component for writing narrative paragraph of both groups are different. Using pictures story is better than conventional way in improving the students' mechanics of writing.

\subsection{The T - Test of the Students' Writing}

The $t$ - test of the students' writing of each component observed were described in the following tables:

Table 20. The $t$ - test of the students 'writing of content component.

\begin{tabular}{llll}
\hline Types of Test & Variable & $\mathbf{t}$ - test Value & t -table \\
\hline Pretest & $X_{1}-X_{2}$ & -0.717 & 2.000 \\
Posttest & $X_{1}-X_{2}$ & 2.049 & 2.000 \\
\hline
\end{tabular}


The table above shows that $\mathrm{t}$ - test value of content component of the students' writing narrative paragraph. Based on the analysis, the researcher can conclude that after giving treatment by using pictures story, the students' writing skill in content component can be improved.

Table 21. The t-test of the students 'writing of organization component.

\begin{tabular}{llll}
\hline Types of Test & Variable & t -test Value & t -table \\
\hline Pretest & $\mathrm{X}_{2}-\mathrm{X}_{1}$ & 1.112 & 2.000 \\
Posttest & $\mathrm{X}_{2}-\mathrm{X}_{1}$ & 2.355 & 2.000 \\
\hline
\end{tabular}

The table above shows that $t$ - test value of organization component of the students' writing narrative paragraph. Based on the analysis, the researcher can conclude that after giving treatment by using pictures story, the students' writing skill in organization component can be improved.

Table 22. The $t$ - test of the students' writing of vocabulary component

\begin{tabular}{llll}
\hline Types of Test & Variable & t - test Value & t - table \\
\hline Pretest & $X_{2}-X_{1}$ & 1.442 & 2.000 \\
Posttest & $X_{2}-X_{1}$ & 2.526 & 2.000 \\
\hline
\end{tabular}

The table above shows that $t$ - test value of vocabulary component of the students' writing narrative paragraph. Based on the analysis, the researcher can conclude that after giving treatment by using pictures story, the students' writing skill in vocabulary component can improved.

Table 23. The $t$ - test of the students'writing of language use component.

\begin{tabular}{llll}
\hline Types of Test & Variable & t -test Value & t -table \\
\hline Pretest & $\mathrm{X}_{2}-\mathrm{X}_{1}$ & 0.843 & 2.000 \\
Posttest & $\mathrm{X}_{2}-\mathrm{X}_{1}$ & 2.020 & 2.000 \\
\hline
\end{tabular}

The table above shows that $t$ - test value of language use component of the students' writing narrative paragraph. Based on the analysis, the researcher can conclude that after giving treatment by using pictures story, the students' writing skill in language use component can be improved

Table 24. The $t$ - test of the students 'writing of mechanics component.

\begin{tabular}{llll}
\hline Types of Test & Variable & t -test Value & t - table \\
\hline Pretest & $\mathrm{X}_{2}-\mathrm{X}_{1}$ & 1.419 & 2.000 \\
Posttest & $\mathrm{X}_{2}-\mathrm{X}_{1}$ & 2.808 & 2.000 \\
\hline
\end{tabular}

The table above shows that $\mathrm{t}$ - test value of mechanics component of the students' writing narrative paragraph. Based on the analysis, the researcher can conclude that after giving treatment by using pictures story, the students' writing skill in mechanics component can be improved.

After calculating the result of the students pretest and posttest, the researcher presented the $t$ - test in the following table:

Table 25. The $t$ - test of the students'writing test $\left(X_{2}-X_{1}\right)$

\begin{tabular}{llll}
\hline Types of Test & Variable & t - test Value & t - Table \\
\hline Pretest & $X_{2}-X_{1}$ & 1.020 & 2.000 \\
Posttest & $X_{2}-X_{1}$ & 2.634 & 2.000 \\
\hline
\end{tabular}

The table above shows that $\mathrm{t}$ - test value is greater than $\mathrm{t}$ - table value of the students' writing narrative paragraph. Based on the analysis, the researcher can concluded that there was significance different between then mean score of the students in pretest and posttest.

In order to know whether or not the mean difference of both variables are statistically significant at the level significance 0.05 with degrees of freedom $(d f=76$ for pretest and 74 for posttest) or $\left(n_{1}+n_{2}-2\right), t$ - test statistical analysis $\mu$ independent sample was employed.

\subsection{Hypothesis}

After applying $\mathrm{t}$ - test for non-independent sample in calculating the difference of the students' writing skill between the experimental and control group, it is found that the $\mathrm{t}$ - test value (2.634) is higher than $\mathrm{t}$ - table value (2.000). It means that the null hypothesis is rejected and the alternative hypothesis is accepted. It can be concluded that the students who were taught by using pictures story were better than the students who were taught by conventional way. The use of pictures story improved significantly the writing skill of first year students of SMA Negeri 3 Parepare. The researcher can say that teaching writing by pictures story is better than teaching writing by using conventional way.

\section{Discussions}

In research, it finds that teaching by using pictures story can improve the students' writing skill. The students who are taught by using pictures story have better performance in writing than the students who are taught by using conventional way although the researcher did same treatment in two groups, for example the researcher divided the students in experimental into small group. The researcher also divided control into small group. Moreover, it shows in the application of t-test for two groups in posttest, where $t$ test value is higher than $\mathrm{t}$ - table value although only few point.

This research supports some previous researches as conducted by Lara in 2004. She found that using an outlines as source of material or ideas for writing can improve the student's writing ability. In same year, Liku also found that using journal as a source of material can increase the student's writing skill.

In addition, Sitti Rahma in 2005 compared between two groups and found that the students who were taught through direct observation is better than without taught by using direct observation. Meanwhile in 2006, Fatmawati found that real object observation could improve the students writing ability. At the same year, Awaluddin also found of his research that the using of spider web is effective to improve the students writing skill.

After using pictures story, the researcher finds that pictures story can improve five components of writing in experimental group. It supports of $\mathrm{t}$ - test value in each component of writing is higher than $t$ - table value. Meanwhile in 2005, Sitti Rahma compared two groups who were taught through direct object observation and without 
taught direct object observation in writing descriptive paragraph. She found that using direct object observation could improve the students' writing skill. However in mechanics component, she did not found any significant improvement. Meanwhile the other researchers only compare the students in one group who treated by using outlines, journal, real object observation and spider web. Therefore, the researcher believes that the use of pictures story is better to improve the students writing skill than the other methods who found the previous researchers.

\section{Acknowledgements}

This research was supported by The Higher Education Directorate of Indonesia and Sekolah Tinggi Keguruan dan Ilmu Pendidikan (STKIP) Muhammadiyah Rappang, Indonesia. The researcher thank his mentors from Prof. Dr. Baso Jabu, M.Hum (State University of Makassar) and Prof. Dr. Haryanto, M.Pd. (State University of Makassar) who provided insight and expertise that greatly assisted the research.

\section{References}

[1] Ali, Aschawir. 2009. Using Series Pictures to Improve the Writing Skill of English Department Stuidents of Letter Faculty of Indonesia Moslem University. Unpublished Thesis. Makassar: PPs UNM.

[2] Awaluddin 2006. Improving Writing Skill of the Second Year Students of SMA Negeri 1 Duampanua Kabupaten Pinrang by Using Spider Web. Thesis. FKIP Universitas Muhammadiyah Parepare.

[3] Bacon, Marks. 1998. Write like Prose: Using the Secret of Writers and Journalist in Business. New York: John Willey and Sons, Inc.

[4] Brainy,Dictionary.2007a. Definition of Picture. (Online), http://www.brainydictionary.com/words/pi/picture202820.htm 1 , retrieved February $2^{\text {nd }}, 2012$

[5] Brown, H. Douglas.2001. Teaching by Principles: An Interactive Approach to Language Pedagogy. San Francisco: Addition Wesley Longman, Inc.

[6] Byrne, Donn. 1984. English Teaching Perspective. London: Longman.

[7] Cassandra. 2006. How to Write a Narrative Story?. Retrieved February $\quad 2^{\text {nd }}, \quad 2012, \quad$ from http://www.associatedcontent.com/article/45928/how_to_writ e a narrative story.html? cat $=4$.

[8] Depdiknas. 2006. Kurikulum 2006: Standar Kompetensi SMA/MA. Jakarta: Dharma Bakti.

[9] Elih Sutisnayanto. 2011. An Analysis of School Based English Curriculum KTSP. Retrieved February 2nd, 2012, from http://elihsutisnayanto.wordpress.com/2011/02/12/an-analysisof-school-based-english-curriculum-ktsp/
[10] Gay, L.R. 1981. Educational Research; Competencies for Analysis \& Application (Second Edition). Charles E. Merrilill Publishing Company. A bell \& Howell Company.

[11] Gay, L. R., et al. 2006. Educational Research Competencies for Analysis and Applications: Eight Edition. Columbus Ohio. Pearson Merril Prentice Hall.

[12] Ghaith, Ghazi. 2002. Writing. Retrieved February $2^{\text {nd }}, 2012$, from http://www.thefreedictionary.com/writing.

[13] Gillie, et al,. 2001. An Integrated Course for Nonnative Speakers of English. Mc Graw Hill. Singapore.

[14] Hornby, AS. 1974. Oxford Advanced Learner's Dictionary of Current English. The Third Edition. Oxford University Press.

[15] Hughes, Arthur. 2008. Testing for Language Learners, UK: Cambridge University.

[16] Iryani. 1998. The Ability of the Fifth Semester Students of English Department of FBS IKIP Ujungpandang to compose Descriptive Pargraph Using Familiar Pictures. Thesis FBS UNM.

[17] Kasman, M. 2003. Using Remedial Teaching to Improve the Writing Ability of SLTP Students. Thesis. FKIP Universitas Muhammadiyah Parepare.

[18] Kilickaya, Ferit. 2004. Authentic Materials and Cultural Content in EFL Classrooms. The Internet TESL Journal. Retrieved February $2^{\text {nd }}, \quad 2012, \quad$ from http://iteslj.org/Techniques/Kilickaya-AutenticMaterial.html.

[19] Nakhdah. 2004. The Ability of the Second Year Students of SMP Negeri 9 Parepare to Write Guided Composition in English. Thesis. FKIP Universitas Muhammadiyah Parepare.

[20] Pincas, Anita. 1986. Writing in English, Book 2. London: Macmillan.

[21] Przybyla, Daria. 2009. Definitions and Examples of Different Kind of Paragraphs. Retrieved February $2^{\text {nd }}, 2012$, from http://academicwriting.suite101.com/article.cfm/example_of a_narrative_paragraph

[22] Spencer, L. 2005. A Step-by-Step Guide to Narrative Writing. Retrieved March 2nd, 2010, from http://grammar.about.com/od/mo/g/narrative2term.htm.

[23] Simard, Jean. 1997. The Writing Process in a Multimedia Environment. Retrieved February 2 $2^{\text {nd }}, 2012$, from http://technologysource.org/article/.

[24] Subroto, H. 2003. The Ability of the Third Year Students of SMU Negeri 4 Parepare to Use Verbs in Writing Narration. Thesis. FKIP Universitas Muhammadiyah Parepare.

[25] Sugiyono. 2010. Statistika untuk penelitian. Bandung: Alfabeta.

[26] Wells, Gardin. 1993. Writing: the Hobby about that Pays. Singapore. EPB Publisher Ptc. Ltd.

[27] Zenger, 1991. Advantages using pictures story. Retrieved February $5^{\text {th }}$ 2012, from www.shvoong.com/writing-andspeaking/branded-content/2103882-advantages-usingpictures-story/\#ixzzlsJNy9rnh. 